\title{
Welfare and Education in British Colonial Africa, 1918-1945
}

\author{
Peter Kallaway
}

The relevance of historical research for an explanation of the roots of contemporary educational policy and its relationship to notions of equity, democracy and development has been sadly neglected in recent years. This means that policy makers have forfeited the advantages of reflecting on the traditions and experience of past endeavors and examining them critically for potential understandings of present and future policy making. The aim of this paper was to direct the attention of researchers to the complexities and multifaceted nature of educational policy development in inter-war era (1918-1945), with specific reference to British colonial Africa and South Africa. It will also hopefully provide a set of elementary tools for all of those interested in educational policy-making strategies that seek to promote meaningful social, economic and political change in an age of uncertainty.

Current discussion about the decolonization of education raises important questions about the nature of colonial education and requires researchers to avoid the reification of such notions if we are to gain an

P. Kallaway $(\bowtie)$

University of Cape Town/University of the Western Cape,

Cape Town, South Africa

e-mail: peter.kallaway@uct.ac.za

(C) The Author(s) 2020

D. Matasci et al. (eds.), Education and Development in Colonial

and Postcolonial Africa, Global Histories of Education, https://doi.org/10.1007/978-3-030-27801-4_2 
ample understanding of their meaning for the present. It is important therefore to understand the complexities of educational discourse, policy and practices in colonial contexts in precisely the same way that we need to understand the entanglements of education policy discussion at the present time. As stated by the editors in the introduction to this volume, it is essential to understand the ambiguities and contradictions of educational policy and practice, the variety of influences that informed such changes, and the changing nature of such discourses over time and in different geographical locations. We also need to be careful to distinguish between rhetoric and reality in education policy. What policy makers say about policy is not always the same as what they do in complex real-life situations.

The task of "development" in Africa in the post-World War II era was reconstituted within the frameworks that were evolved by the agencies of the United Nations Organization and the World Bank. Within the optimistic atmosphere of the post-colonial politics of the 1950s and 1960s, a new infrastructure of "development studies" was constructed, with the backing of generous donations of foreign aid-much of it coming from the former colonial powers. Since then, the works of Hetherington, Constantine, Hargreaves, Darwin, Cell, Hodge, Tilley and Cooper have helped us to understand more fully why that gap between intentions and outcomes was often so marked. ${ }^{1}$ A key element of their work is to elucidate the nature of the rickety scaffolding of emergent statesponsored welfarism, philanthropic humanitarianism, scientific management and research, upon which this emergent enterprise of "development" was built in the inter-war era. In that context, I wish to address some comments to the question of the conceptualization of colonial education during this period and then relate it to the wider issue of welfare policies that provided the backdrop to much of this work.

\footnotetext{
${ }^{1}$ Penelope Hetherington, British Paternalism and Africa (London: Frank Cass, 1978); John D. Hargreaves, Decolonization in Africa (London: Longman, 1988); Stephen Constantine, The Making of British Colonial Development Policy 1914-1940 (London: Frank Cass, 1984); John Darwin, "Decolonization and the End of Empire," Oxford History of the British Empire, vol. V (Oxford: Oxford University Press, 1999), 541-557; John Cell, Hailey: A Study of British Imperialism, 1872-1969 (Cambridge: Cambridge University Press, 1992); Joseph M. Hodge, Triumph of the Expert: Agrarian Doctrines of Development and the Legacies of British Colonialism (Athens, OH: University of Ohio Press, 2007); Helen Tilley, Africa as a Living Laboratory (Chicago: University of Chicago Press, 2011); Frederick Cooper, Africa Since 1940: The Past of the Present (Cambridge: Cambridge University Press, 1996).
} 


\section{Conceptualizing Colonial Education}

It is not possible to gain a comprehensive understanding of the development of educational policy in colonial Africa without a detailed study of the complexities of colonial educational discourse as it played itself out in the context of a worldwide revolution in educational thinking between the mid-nineteenth century to the mid-twentieth century. The influence of humanism, the legacy of the French Revolution, the impact of the Industrial Revolution and the movements for political and social reform, the challenges of mass education for a newly urbanized working class, the advent of vocational and technical education, the impact of the vast changes in the nature of science and technology, all contributed to the ferment of ideas that informed "Progressive Education," "vocational education" and "radical education" during the late colonial era (see Chapter 5 by Jakob Zollmann and Chapter 7 by Michael A. Kozakowski). These all impacted on the manner in which education, pedagogy and curriculum were conceived globally by a variety of actors in various context at different times, ${ }^{2}$ and more specifically in relation to the African colonial context.

The origins of the story of mass education in England are to be found in Sanderson's description of the central policy dispute over education in the nineteenth century which was waged between those who wished to explain the provision of mass education as part of an attempt to ward off radical political and economic change by an increasingly organized urban working class, and those who saw the social reforms through education as a means of extending democratic rights, social welfare and human dignity in modern society increasing divided by class divisions. ${ }^{3}$ The essential ambiguities of mass education in industrial countries were reproduced in the colonial context. Was colonial education to be about creating African Christians/African workers/African subject/citizens who were to be the vanguard of social, economic and political modernization and perhaps Westernization (assimilation for the French) or was

${ }^{2}$ Andy Green, Education and State Formation: The Rise of Education Systems in England, France and the USA (London: Macmillan, 1990); David Tyack and Larry Cuban, Tinkering Toward Utopia: A Century of Public School Reform (Cambridge: Harvard University Press, 1995); Harold Silver, Equal Opportunity in Education (London: Methuen, 1973).

${ }^{3}$ Michael Sanderson, Education, Economic Change and Society in England, 1780-1870 (London: Macmillan, 1983). 
the role of the school and missions to prevent such modernization and radicalization by facilitating more productive life on the land for peasant farmers and contented "tribesmen" or educated indigenes who would not threaten the colonial order? ${ }^{4}$

My broad focus is on the construction of a modern network of educational experts drawn from missionary, state and philanthropic backgrounds, who framed a context for professional debate and policy practice in the inter-war era. The origins of many of these debates about colonial education can be traced to the great ecumenical Edinburgh International Missionary Council (IMC) conference in $1910 .^{5}$ From this time, there was an attempt to establish consultative networks of experts who would engage with issues of African education. For the most part, these experts were missionaries and government officials, but after World War I, the grid was expanded to include philanthropic contributions (mainly from American foundations like Carnegie, Rockefeller, Jeanes and Phelps Stokes) and a variety of progressive educators and university-based educators located mainly at institutions like Teachers College, Columbia University, the Institut Jean-Jacques Roussean in Geneva, the École Coloniale in Paris, and, from the 1930s, and the Institute of Education, at London University. Through these networks which were crafted via various Imperial Education conferences between 1907 and the 1930s, ${ }^{6}$ IMC congresses at Le Zoute, Belgium (1923), Jerusalem (1926), Tambaram, India (1938), ${ }^{7}$ New Education Fellowship (NEF) meetings during the 1920-1930s in Europe, South Africa and

\footnotetext{
${ }^{4}$ Martin Carnoy, Education and Cultural Imperialism (New York: David McKay, 1974); Keith Watson (ed.), Education in the Third World (London: Croom Helm, 1982); Peter Kallaway and Rebecca Swartz (eds.), Empire and Education in Africa (New York: Peter Lang, 2017).

${ }^{5}$ Peter Kallaway, "Education, Health and Social Welfare in the Late Colonial Context: The International Missionary Council and Educational Transition in the Inter-War Years with Specific Reference to Colonial Africa," History of Education 38, no. 2 (2009): $217-$ 246; Felicity Jensz, "The 1910 Edinburgh World Missionary Conference and Comparative Colonial Education," History of Education 47, no. 3 (2018): 399-414.

${ }^{6}$ British Parliamentary Papers (BPP) Col. 5666 (1911); BPP Col. 1990 (1923); BPP Col. 2009 (1924); BPP Cmd. 2883 (1927); BPP Cmd. 3628-9 (1930); W. Rawson (ed.), Education in a Changing Commonwealth (London: HMSO, 1931).

${ }^{7}$ Kallaway, "Education, Health," 217-246.
} 
Australasia ${ }^{8}$ and the Yale Education conferences convened by the South African, C. T. Loram, with the assistance of American philanthropic foundations between 1934 and 1939, 9 a research community gradually emerged which had a degree of influence on colonial education policy and practice.

The origins of the scientific study of colonial education can be traced to this time and to this context. The variety of reports of the English Board of Education (1897-1914), which included a considerable contribution on colonial education, ${ }^{10}$ and the Hamburg Colonial Institute's report on Education in the German Empire (the Schlunk Report of 1914), ${ }^{11}$ were probably the first attempt to compile data and information on education on a large scale informed by modern statistical methods and a scientific approach to colonial educational policy. ${ }^{12}$ These were followed by the two major Phelps Stokes Commission Reports on African education in 1922 and 1924, sponsored by an alliance of American missionary and philanthropic endeavor. ${ }^{13}$ In a context where "the assumed stability of colonial rule became more questionable during the 1930s, a certain number of persons in Britain and France conceived programmes of reform and renewal which would eventually lead towards the

\footnotetext{
${ }^{8}$ Peter Kallaway, "Conference Litmus: The Development of a Conference and Policy Culture in the Inter-War Period with Special Reference to the New Education Fellowship and British Colonial Education in Southern Africa," in Transformations in Schooling: Historical and Comparative Perspectives, ed. by Kim Tolley (New York: Palgrave Macmillan, 2007), 123-149.

${ }^{9}$ These Conferences on colonial education were held in New Haven (1934), Salisbury, Southern Rhodesia (1935), Hawaii (1936); North Carolina/Colorado (1937), Toronto (1939).

${ }^{10}$ UK Board of Education, Special Reports on Educational Subjects, 1897-1914. The publication most relevant to this topic is vol. V: "Education Systems in the Chief British Colonies of the British Empire," House of Commons Sessional Papers, vol. XXII, p. 1/1 (1900).

${ }^{11}$ Martin Schlunk, Die Schulen für Eingeborene in den deutschen Schutzgebieten (Hamburg: Hamburgischen Kolonialinstituts/L. Freidrichsen \& Co., 1914).

${ }^{12}$ It is important to note that the annual reports of the Department of Public Education in the Cape Colony also offer a remarkable depth of evidence from the middle of the nineteenth century.

${ }^{13}$ Thomas Jesse Jones, Education in Africa (New York: Phelps Stokes Fund, 1922); Education in East Africa (New York: Phelps Stokes Fund, 1924).
} 
independence of the African colonies," 14 but the pace of such reforms needs to be understood in incremental terms with only the gradual emergence of broad plans for social reform.

In the field of education, the first landmark in this regard took the form of the Colonial Office (CO) statement on Education Policy in British Tropical Africa (1925). ${ }^{15}$ These initiatives provided the template for much debate into the 1930s regarding the nature of the school curriculum and the extent of state support for education. Here, the major emphasis was on adapted education to support Lord Lugard's policy of Indirect Rule ${ }^{16}$ and a "Progressivist" agenda of rural community education that had initially been piloted in the postbellum South of the USA. ${ }^{17}$ Out of these initiatives, there emerged the beginning of a "scientific approach" to education and policy development to replace the previous dependence on the field experience of missionaries and colonial officials. This new approach was based in part upon the linkages between management and science that were being forged in relation to business and education in the USA. ${ }^{18}$ The move by the CO to establish the Advisory Committee on Native Education in Tropical Africa (ACNETA) in 1923, subsequently called the Advisory Committee for Education in the Colonies (ACEC), marked a clear, if tentative, initiative to formalize educational policy discussion in an age of increasing uncertainty. Other significant $\mathrm{CO}$ Memos which will be referred to below were: The Place of the Vernacular in Native Education (1927) ${ }^{19}$; A Biological Approach

${ }^{14}$ Hargreaves, Decolonization in Africa, 2.

${ }^{15}$ Colonial Office (CO) Cmd. 2347, 1925.

${ }^{16}$ Lord Lugard, Dual Mandate in Tropical Africa (London: Frank Cass, 1922). A parallel text for French Africa was Albert Sarraut, La Mise en valeur des Colonies francaises (Paris: Payot, 1923). See also Anon, "Indirect Rule in Africa and Its Bearing on Educational Development," Overseas Education IV, no. 1 (1932): 82-84.

${ }^{17}$ Kenneth King, Pan-Africanism and Education: A Study of Race Philanthropy and Education in the Southern States of America and East Africa (Oxford: Clarendon Press, 1971).

${ }^{18}$ Lawrence A. Cremin, The Transformation of the School "Progressivism" in American Education 1876-1957 (New York: Vintage, 1964); David Labaree, Education, Markets and the Public Good (London: Routledge, 2007); Diane Ravitch, Left Back: A Century of Failed School Reforms (New York: Simons \& Schuster, 2001).

${ }^{19}$ CO: ACNETA: Africa, No. 1110: 1927. 
to Native Education in East Africa $(1930)^{20}$; Compulsory Education in the Colonies (1930) $)^{21}$; Grants-in-Aid to Education (1930) ${ }^{22}$; Education of African Communities (1935) ${ }^{23}$; Mass Education in African Societies $(1944)^{24}$; and Education for Citizenship (1948). ${ }^{25}$

This led to the emergence of further influences on policy development-namely its increasing association with science and research-the expanded role of Universities and "educational experts" in training educators and conducting research, with the gradual shaping of a research culture which was expected to be "relevant" to policy concerns. This demonstrated the first signs of state intervention in welfare and education issues, despite very constrained budgets for research, and demonstrated that mission and state were to forge new alliance to meet the increasing demand for education, health and welfare services, parallel to the increasingly complex issues raised by the volatile political atmosphere in the international arena and in the African colonial context from the 1930s.

The IMC launched its own initiatives in this regard by establishing a Department of Social and Industrial Research in $1930,{ }^{26}$ but it was mainly through the efforts of the International Institute of African Languages and Culture (IIALC), ${ }^{27}$ funded by the Rockefeller Foundation, that most of this work was to be pursued. ${ }^{28}$ In that context, it was widely held that the emergent discipline of social anthropology held the keys to the evolution of expertise which would enable more efficient, and perhaps even more just, government/governance of the empire. There was as a result an extended association between colonial

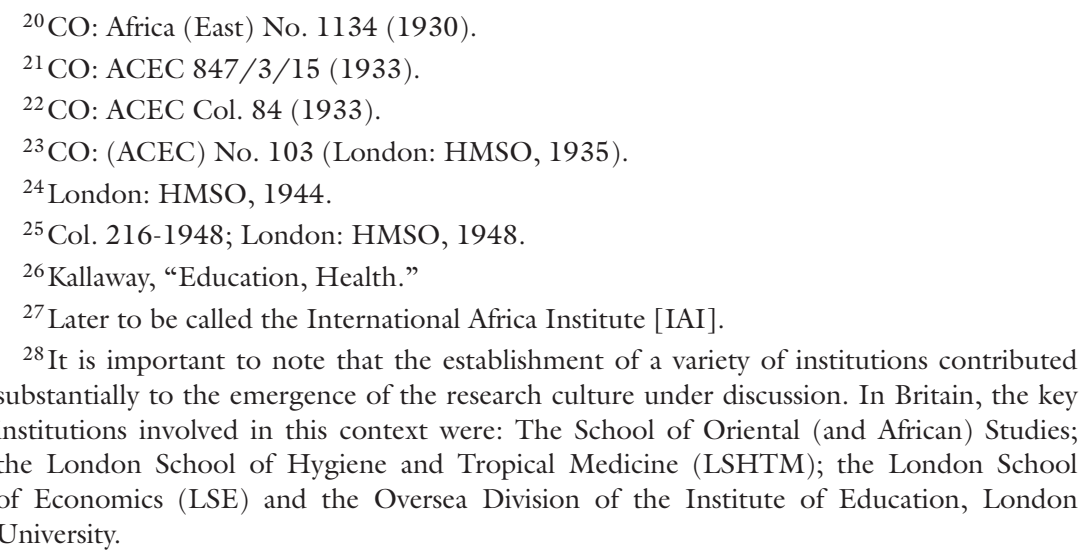


education and anthropology, though the outcomes of that exercise did not prove particularly promising from the point of view of the officials charged with framing and implementing policy. ${ }^{29}$ For all that, leading anthropologists like Malinowski at the London School of Economics made great claims for the relevance of this research for addressing the issue of "culture contact" which he asserted was central to understanding the dynamic of the colonial situation. ${ }^{30}$

German missionaries, both under the Kaiser and from the 1920s when they returned to the African mission field, focussed on issues of culture in education which had played a dominant role in the establishment of a German national identity since the 1880s. They were better equipped with the scientific tools of modern research than most other missionaries, and particularly in the East African context, they argued for an increased focus on indigenous cultures and languages in the development of African education-in part because this was the most effective means for proselytization. This view was defended by a range of progressive education arguments in favor of the use of the vernacular as a medium of instruction in education. The work of German linguists like Diedrich Westermann, who had senior posts both at Berlin University and the IIALC in London, aimed at the promotion of African languages and securing the textbooks and materials to make indigenous language instruction viable in West, East and Southern Africa. ${ }^{31}$

Another theme that informed colonial education in East Africa in the early 1930s was the attempt to promote secular and scientific education in the schools. This was defended in terms of the need to 'modernize' education and strengthen modern secular knowledge in a field

\footnotetext{
${ }^{29}$ Peter Kallaway, "Science and Policy: Anthropology and Education in British Colonial Africa During the Inter-War Years," Paedagogica Historica 48, no. 3 (2012): 411-430.

${ }^{30}$ Bronislaw Malinowski, "The Rationalization of Anthropology and Administration," Africa 3, no. 4 (1930): 405-430; "Native Education and Culture Contact," International Review of Missions 25 (1936): 480-515.

${ }^{31}$ Peter Kallaway, "Volkskirche, Völkerkunde and Apartheid: Lutheran Missions, German Anthropology and Science in African Education," in Contested Relations: Protestantism Between Southern Africa and Germany from the 1930s to the Apartheid Era, ed. by Hanns Lessing, Tilman Dedering, Jürgen Kampmann, and Dirkie Smit (Wiesbaden: Harrassowitz Verlag, 2015), 155-176; "Diedrich Westermann and the Ambiguities of Colonial Science in the Inter-War Era," Journal of Imperial and Commonwealth History 45, no. 6 (2017): 871-893.
} 
dominated by missions. The drafting of a Memo on Biology and its place in Native Education in East Africa, ${ }^{32}$ promoted by the British Social Hygiene Council (BSHC), was also aimed at introducing a science-based core curriculum that would counter what were considered to be pagan beliefs or the promote healthcare and economic development. This secular/scientific approach to education was linked to international trends which highlighted progressive pedagogy and the promotion of student motivation which sought to move away from the older tradition of passive rote-learning. Educational curricula were to focus on environmental awareness-plants, animals, agriculture, hygiene, nutrition, economic environment - and the role of women and children in society. The linking of the politics and policy of education to wider issues of welfare and society, that were increasingly being stressed by the League of Nations, reflected contemporary political and economic concerns in Britain and Europe in the 1930s. As indicated above, they came to have a significant bearing on policy development in the colonial context.

\section{WeLFARE AND EDUCATION}

It is important to see the increasing attention to education in the context of wider attempts by the actors referred to above to come to grips with the variety of challenges presented to colonial government in the interwar years. In this context, there was a broad attempt to establish the elements of a welfare system in British African colonies, by promoting research into areas such as health, child welfare, nutrition, juvenile delinquency, the education of women and girls, as well as adult and higher education from the time of the first Colonial Development Act (1929) to the Colonial Development and Welfare Act of 1940. ${ }^{33}$ The establishment of an Advisory Committee on Social Welfare (1943) represented a colonial postscript to the wartime Beveridge Report on Social Welfare in

\footnotetext{
${ }^{32}$ Julian Huxley, Biological Approaches to Native Education in East Africa (CO Africa (East) No. 1134 (1930); Biology and Its Place in Native Education in East Africa (London: HMSO, 1930).

${ }^{33}$ BPP Colonial Welfare and Development Act (1940); Cmd. 6175-1940 Statement of Policy on Colonial Development and Welfare (London: HMSO, 1940). For the Reports of the Colonial Development Fund for 1929-1941 see BPP Cmd. 3540, 3876, 4079, 4316, $4634,4916,5202,5537,5789,6062,6298$.
} 
the UK. ${ }^{34}$ The establishment of a Social Services Department at the CO in 1939 represented a milestone. Although little was achieved in terms of the implementation of broad welfare plans, given the weakness of colonial states and the shortage of financial resources due to the war, there is evidence of some degree of concern with issues that would be taken up more fully at a later time. ${ }^{35}$ Following on the work of Hetherington, Hodge and Tilley, I will therefore attempt to identify those areas that were highlighted in the process in the hope that others will explore them further. As a supplement to this enquiry, I will also indicate to what extent such welfare measures were to influence South Africa during this period prior to the advent of apartheid from 1948. I will refer to the provisional proposal for a national health and welfare system from 1939, and concern for issues such as nutrition (school feeding schemes), juvenile delinquency and vocational education. The key references for these events are the report of the National Conference on Social Work (1937), the establishment of a Department of Social Welfare (1937), the report of the commission to investigate the feasibility of a National Health Service (the Gluckman Report, 1944) and a Report on Social Security (the Batson Report, 1944). ${ }^{36}$

It is important to note at the outset that the use of the term "development" changes during the time under review, and this has considerable

${ }^{34}$ UK. Cmd. 6404 (1942) Report on Social Insurance and Allied Services (Beveridge Report).

${ }^{35}$ BPP Cmd. 6175 (1940) Statement of Policy on Colonial Development and Welfare (London: HMSO, 1940). The report of Sir Frank Stockdale on Development and Welfare in the West Indies paved the way for further thinking about the African context. BPP Colonial No. 189/HMSO, 1945.

${ }^{36}$ Union of South Africa, Report of the National Conference on Social Work (Johannesburg: Government Printer, 1937); U.G. No. 30-1944: National Health Services Commission of South Africa (the Gluckman Report): UG No. 14-1944: Report of the Inter-Departmental Committee on Social Security (the Batson Report). For a comprehensive survey of these issues see Ellen Hellman (ed.), Handbook on Race Relations in South Africa (Johannesburg: SAIRR, 1949), Chs. XVI, XVII. See Shula Marks, "Industrialization, Rural Health, and the 1944 National Health Services Commission in South Africa," in The Social Basis of Health and Healing in Africa, ed. by Steven Frierman and John M. Janzen (Berkeley: UCLA Press, 1992), 132-161; David Duncan, "The Origins of the 'Welfare State' in Pre-apartheid South Africa," ICS Collected Seminar Papers (London University, 1992). 
significance for this enquiry. The 1929 Colonial Development Act was entirely focussed on economic development, or growth, and essentially shared the ethos of the Empire Marketing Board (EMB, 1926) which stressed the expansion of the colonial economies as a contribution to the British exchequer and a direct solution to the economic woes of the Depression. It was only successful after a long battle with Treasury over its potential as an element of the solution to the problem of mass unemployment in Britain. ${ }^{37}$ Only incrementally over the course of the 1930s did the term "development" come to take on its modern connotations which focus on the social or welfare aspects of the colonial situation-what Hodge terms "the 'human side' of development." 38 This was reflected in the remarks of Lord De La Warr, the Under-Secretary of State for the Colonies in the late 1930s, when he argued that "the real Development needed in Africa today is not the investment of large sums of capital but the improvement of human capital." 39 This took place in the context of challenges presented by emergent social policy discourse in Britain with the rise of the Labour Party and Fabian influence, the tensions over the meaning of the Empire generated by the Closer Union debate, ${ }^{40}$ and Labour's experiment with the "Doctrine of Native Paramountcy" in East Africa ${ }^{41}$; the rise of fascism and communism in Europe, and, perhaps most significantly, the rise of African nationalism.

The focus on "the African child" and child welfare seems to present a potential litmus test for a sensitivity to wider welfare issues. It also highlights the influence of the League of Nations in focussing attention of the colonial powers on development and welfare issues. The initiative can be traced to the international conferences on the topic held under the aegis of the League of Nations. The CO sent delegates to the first International Congress on Child Welfare in $1925^{42}$ and to the larger

${ }^{37}$ See Constantine, The Making of British, Chs. VI and VII. Constantine notes that the $\mathrm{CO}$ strongly resisted these policies based on economic criteria.

${ }^{38}$ Hodge, Triumph of the Expert, Chapter 4.

${ }^{39}$ Memo by Lord de la Warr, n.d. [1937] Co $852 / 118 / 15279 / 5$ cited by Constantine, The Making..., 221, 230.

${ }^{40}$ See J. H. Oldham, White and Black in Africa: A Critical Examination of the Rhodes Lectures of General Smuts (London: Longmans, 1930).

${ }^{41}$ Robert G. Gregory, Sydney Webb and East Africa (Berkeley: University of California Press, 1962).

${ }^{42}$ PRO CO 854/61-1925. 
International Conference on the African Child (1931), both held in Geneva. Here the issues of child rights and humanitarian concerns took center stage. ${ }^{43}$ It does not seem as if this issue was taken up directly by colonial governments, but it was tackled obliquely in various ways and with varying degrees of success.

In general terms, the health and medical issues relating to the colonial context had focussed on specific issues like the treatment of sleeping sickness or yellow fever prior to 1920 when there was a comprehensive report by a Departmental Committee on Colonial Medical Services. ${ }^{44}$ The CO created the post of a Chief Medical Officers and this remained part of its establishment from 1926 to 1961. In the 1930s, a Colonial Medical Research Fund was initiated with a Committee to oversee its affairs. This led to a joint initiative by the British Medical Association (BMA) and the CO to establish a Medical Research Board. ${ }^{45}$ Two conferences took place in the wake of these moves: one on Medical Research in East Africa (1934) and a Pan-African Health Conference held in Johannesburg in 1935. ${ }^{46}$ Only after World War II was a Director of Colonial Medical Research appointed by the CO. During the War, the South African government also established a Commission to report on the feasibility of a National Health Service on the Beveridge model under the future Minister of Health, Henry Gluckman. ${ }^{47}$ One of the key issues of concern that emerged from these activities was the question of food security and nutrition in Africa. The League of Nations enquiry

${ }^{43}$ Save the Children's Fund, International Conference on the African Child (Geneva: League of Nations, 1931); Evelyn Sharp, The African Child: An Account of the International Conference on African Children, Geneva (S.I. Longman, 1931); Dominique Marshall, "Children's Rights in Imperial Political Cultures: Missionary and Humanitarian Contributions to the Conference on the African Child of 1931," International Journal of Children's Rights 12 (2004): 273-318.

${ }^{44}$ BPP. Cmd. 939, XII, 267, September 1920.

${ }^{45}$ See CO 1931: Papers on the Health and Progress of Native Populations; CO/BMA Report on Health Services in the Empire. See Hodge, Triumph of the Expert, 314; CO $323 / 1112 / 8$.

${ }^{46}$ The Johannesburg event was reported in the Quart. Bull. Hlth. Org., LoN, 5 (1) (1936): 1-209. It was almost entirely concerned with infectious diseases, with few references to social issues.

${ }^{47}$ UG No. 30-1944; Hellman, Handbook on Race, Ch. XVI (see f. 37). 
into this issue produced a comprehensive four-volume report in $1936,{ }^{48}$ which set the tone for a wealth of publications on the topic in the next few years, and this provided the foundation for a variety of initiatives in this field. This was followed by the establishment of Standing Committee on Nutrition in the Colonial Empire under the auspices of the CO Economic Advisory Committee. It produced a report on Nutrition in the Colonial Empire (1938-1939) ${ }^{49}$ and another from the newly established CO Social Services Department in 1943. ${ }^{50}$ Audrey Richards also conducted pathbreaking work in anthropology, by linking ethnographic work to economics and diet in Central Africa. ${ }^{51}$ However, it is difficult to establish to what extent these initiatives were to influence policy in colonial Africa. In South Africa, these trends were reflected by the holding of a National Nutritional Conference hosted by the South African Institute of Race Relations (SAIRR) and the publication of findings on the topic in $1939 .{ }^{52}$ One of the consequences of this event was the establishment of state-sponsored national school feeding scheme in 1941-1942 that was expanded to include black school children. ${ }^{53}$ This policy was in

${ }^{48}$ League of Nations, The Problem of Nutrition (Geneva: LoN, 1936); Final Report of the Mixed Committee of the League of Nations on the Relations of Nutrition to Health, Agriculture and Economic Policy (Geneva: LoN, 1937).

${ }^{49}$ First Report of the Economic Advisory Committee on Nutrition in the Colonial Empire: Part I. Nutrition in the Colonial Empire, Part II. Summary of Information Regarding Nutrition in the Colonial Empire (BPP Pt I: Cmd. 6050; Part II Cmd. 6051) (London: HMSO, 1938-1939).

${ }^{50}$ CO Dept of Social Services, Memo on Nutrition in the Colonial Empire 1943; John Scott, "Education and Nutrition in the Colonies," Oversea Education IX, no. 1 (October 1937): 39-40.

${ }^{51}$ Audrey Richards, Hunger and Work in a Savage Tribe: A Functional Study of Nutrition Among the Southern Bantu (London: George Routledge, 1932); Land, Labour and Diet in Northern Rhodesia: An Economic Study of the Bemba Tribe (London: OUP/IAI, 1939). Reviewed by E. B. Worthington in Africa XIII, no. 1 (1940): 77-82.

${ }^{52}$ SAIRR Journal 6 (3)(1939); "Findings of the Council on Nutrition," SAIRR RR9/40.

${ }^{53}$ See Quentin Whyte, Native School Feeding (Johannesburg: SAIRR, 1949); Union of South Africa, Report of a Committee of Enquiry into the Native School Feeding Scheme (Cillie Commission), 1949. 
operation until the 1950s when it was abandoned by the National Party government in terms of apartheid policy. ${ }^{54}$

Another area of focus in relation to health care, social welfare and education was associated with the role and place of Woman and Children in colonial society. ${ }^{55}$ At one level, this was about the access of this group to welfare services and education. At another, it was concerned about the place of women in society, to what extent they were subject to indigenous law and practices, and to what extent they fell under the legal mandate of the colonial state. The Church Missionary Society conference on "The Education of Women and Girls" in $1925^{56}$ was a precursor to much debate on the topic in the 1930s. In 1927, the Australian-born British educationalist, Amy Whitelaw, and Canon Broomfield reported to ACNETA on the Education of Women and Girls in East Africa. This was followed by a Memo on Education of African Women by Sara Burstall and Whitelaw to the ACEC. Mary Blacklock's work on "The Welfare of Women and Children in the Colonies" was pathbreaking, linking health to social issues and education. ${ }^{57}$

In 1937, the CO produced a document on the topic Welfare of Women in Tropical Africa. ${ }^{58}$ The published correspondence on this paper

\footnotetext{
${ }^{54}$ Peter Kallaway, "Policy Challenges for Education in the 'New' South Africa: The Case for School Feeding in the Context of Social and Economic Construction," Transformation 31 (1996): 1-24.

${ }^{55}$ Clive Whitehead, "The Education of Women and Girls: An Aspect of British Colonial Policy," Journal of Educational Administration and History 16, no. 2 (1984): 24-34; Joanna Lewis, Empire and State-Building: War and Welfare in Kenya, 1925-52 (Oxford: James Currey, 2000), Ch. 1; Janet Welch, "The Goal of Women's Education in Africa," Oversea Education XI, no. 2 (1940): 65-72; Margaret Wrong, "The Education of African Women in a Changing World," in Yearbook of Education (London: Evans Bros., 1940), 497-520.

${ }^{56}$ IMC/CBMS African Education Group, Box 207/243/258/1224/1231/; CO $859 / 4[1-12] 4 / 7$.

${ }^{57}$ Sara Burstall and A. Whitelaw, Memo on the Education of African Women (IMC/CBMS Box 224); Mary Blacklock, "The Welfare of Women and Children in the Colonies," Annals of Tropical Medicine and Parasitology 2 (1936): 221-265.

${ }^{58}$ CO, Welfare of Women in Tropical (London: HMSO, 1937). Also see Correspondence relating to the Welfare of Women in Tropical Africa BPP CO 859/4 [1-12]/ (London: HMSO, 1938).
} 
reveals the complexities of the legal status of women in East Africa and the problem of how this was to be handled by the CO. Between 1940 and 1943, there were a number of reports on the education and welfare of women and girls in Africa including a comprehensive $1943 \mathrm{CO}$ Memo on Women's Education and Welfare in Africa (1943). ${ }^{59}$ Charlotte Hastings has completed an excellent study of the influence of these policies in the specific context of Southern Nigeria in the inter-war years. ${ }^{60}$ In South Africa, there seems to have been little focus on these issues.

Reflecting international trends, the issue of juvenile delinquency attracted systematic attention in some area like Kenya and South Africa where youth crime and antisocial behavior among male Africans was defined as an important social problem in need to state intervention. As Ellen Hellman pointed out in relation to South Africa, this often represented "an attitude of defiance from African and Colored juveniles toward the existing social structure" that required intervention in the form of welfare of some kind. ${ }^{61}$ Between 1933 and 1936, there were four reports on juvenile crime in Kenya which led to the passing of legislation to deal with the problems including the establishment of the Kabete Reformatory near Nairobi. There was also a CO report on Juvenile Welfare in the Colonies in 1942. ${ }^{62}$ In South Africa, legislation was also passed to deal with this issue, but it was initially aimed at white juveniles. There was a government report on the topic in 1937 and a National Juvenile Delinquency conference held in Johannesburg under the auspices of the SAIRR in 1938. ${ }^{63}$ Ellen Hellman's pamphlet on Problems of Urban Bantu Youth ${ }^{64}$ led to an expansion of the system for dealing with these issues, including the passing of a revised Children's Act (UG No. 31-1937) with the extension of Industrial Schools for

\footnotetext{
${ }^{59} \mathrm{CO}$ Report on Education and Welfare of Women and Girls in Africa in 1943. BPP Colonial, No. 1169.

${ }^{60}$ Charlotte Hastings, "Gendered Education Between Metropole and Colony: Sara Burstall, Margaret Faith Wordsworth and Girl's Schooling in Inter-War Southern Nigeria," PhD diss., University of Edinburgh, 2011.

${ }^{61}$ Ellen Hellman, Problems of Urban Bantu Youth (Johannesburg: SAIRR, 1949), 94.

${ }^{62}$ BPP CO 885/103; 859/73/12770/43 (1942); see Chloe Campbell, Race and Empire: Eugenics in Colonial Kenya (Manchester: Manchester University Press, 2006).

${ }^{63}$ UG 38-1937: Report of the Interdepartmental Committee on Destitute, Maladjusted and Delinquent Children and Young Persons, 1934-1937.

${ }^{64}$ Hellman, Problem of Urban.
} 
whites, and the establishment of Ottery School of Industries for Colored boys in Cape Town and Diepkloof Reformatory in Johannesburg for Africans, but the facilities supplied for African and Colored youth were always grossly inadequate. ${ }^{65}$

In addition to the above measures, the provision of education gradually drew greater attention during from the 1930s. In addition to the four major Memos on topic in 1933, 1935, 1944, 1948, cited above, there were also a variety of attempt to focus on technical and vocational education ${ }^{66}$ and higher education. ${ }^{67}$ In South Africa, there was also a flurry of activity relating to these issues during the war years relating to adult education and technical/vocational education. ${ }^{68}$ Much of this related to the provision for whites, but there were indications of the relaxation of the color bar in the interests of economic growth and a broadening of the social security net.

${ }^{65}$ Linda Chisholm, Reformatories and Industrial Schools in South Africa: A Study of Class, Colour and Gender in the Period Between 1882 and 1939, PhD diss., University of the Witwatersrand, 1989 (unpublished); Azeem Badroodien, A History of the Ottery School of Industries in Cape Town: Race, Welfare and Social Order in the Period 1937 to 1968, PhD diss., University of the Western Cape, 2000 (unpublished); Alan Paton, Diepkloof: Reflections on Diepkloof Reformatory (Cape Town: David Philip, 1987).

${ }^{66}$ Lord Hailey, An African Survey (Oxford: Oxford University Press, 1938), 12431248; Survey of Vocational Agricultural Education in the Colonial Empire (CO Col. 124) (HMSO, 1937); Survey of Vocational in Colonial Empire (Col. 177-1940) and Survey of in the Colonies (report by F. J. Harlow) ACEC (53)19: 1953. In 1960, William McLean prepared a briefing for parliament "Notes on in the Colonies" Memo. 24B (1960).

${ }^{67}$ Hailey, An African Survey, 1248-1250; CO ACEC Misc. 423: Report on Higher Education in East Africa (Currie Commission, 1932-1933); BPP Col. No. 142: Report of the Commission on Higher Education in East Africa (de la Warr Commission) (CO 8467/9/6 (1937), HMSO, 1937); Report of the Commission in Higher Education in West Africa (Elliott) (Cmd. 6647; 6654; 6655/HMSO, 1945); Report on Higher Education in West Africa (Ashby) (Lagos; Government Printer, 1960). It is important to note that some of this motivation for the expansion of HE in Africa came from the fear that Africans studying abroad, and particularly in the USA, might be exposed to radical influences inimical to colonial rule. See Appolos O. Nwauwa, "The British Establishment of Universities in Tropical Africa, 1920-48: A Reaction Against the Spread of American 'Radical' Influences," Cahiers d'études africaines 130 (1993): 1247-1274; Kenneth King, Pan-Africanism and Education.

${ }^{68}$ Select Committee on Adult Education (Eybers) (SA Official: UG 35-1945); Select Committee on Technical and Vocational Education (De Villiers), SA Official: UG 65-1948. 


\section{CONCLUSION}

These various political, scientific, religious, philosophical and humanitarian themes contested the policy terrain in colonial Africa and were joined up in multiple ways against the background of the debates about Keynesian economics and social welfare that were the informing political debate about education in Europe and the America during the 1930s. Lord Hailey's great An African Survey made an effort to place all the debates about African development within a scientific and analytical framework. ${ }^{69}$ Education was a key issue of contestation in the context of future policy concerns relating to the nature of "development." Although "adapted education" was not entirely abandoned, and although the culturalist vision of the German linguistics and anthropologists was not forsaken, formal curriculum models based on international norms for formal mass schooling retained their popularity with African educators, parents and students and had a conservative influence on the nature of the school and the curriculum in the years beyond 1945, inhibiting radical educational reform.

The goal of widening access to schooling was a constant refrain, but the lack of resources in these fragile colonial states restricted this expansion. By the advent of World War II, little had been accomplished with regard to the establishment of comprehensive welfare or schooling systems. Yet, as Hodge demonstrates, it was "on the basis of these fragile (policy) constructions that the key policy objectives on which the postwar colonial development offensive would hinge." 70 Although beyond the scope of this enquiry, recent research indicates that many of the initiatives which dated from this time provided the scaffolding for the task of "development" in the very different context of independent Africa from the 1950s referred to by Hans Weiler. The strands of development policy were subsequently reconstituted within the frameworks that were evolved by the agencies of the United Nations Organization and the World Bank. Within the optimistic atmosphere of the post-colonial politics of the 1950s and 1960s, a new infrastructure of "development studies" referred to above was created. Yet, as Hans Weiler noted graphically, that project was best understood as an aspect of an "Age of Innocence"

${ }^{69}$ Hailey, An African Survey; Hodge, Triumph of the Expert; Tilley, Africa as a Living Laboratory (2011).

${ }^{70}$ Hodge, Triumph of the Expert, 143. 
Table 2.1 Welfare and education in colonial Africa and South Africa, 1910-1945

\begin{tabular}{|c|c|c|c|}
\hline Date & Britain & British Africa & South Africa Union \\
\hline 1910 & $\begin{array}{l}\text { IMC Conference, } \\
\text { Edinburgh }\end{array}$ & & \\
\hline 1911 & $\begin{array}{l}\text { Imperial Education } \\
\text { Conference }\end{array}$ & & \\
\hline 1914-1918 & & World War I & \\
\hline 1917 & & & $\begin{array}{l}\text { C. T. Loram, Native } \\
\text { Education in South } \\
\text { Africa }\end{array}$ \\
\hline 1919 & & $\begin{array}{l}\text { East African Education } \\
\text { Commission }\end{array}$ & \\
\hline 1922 & & $\begin{array}{l}\text { Lugard, Dual Mandate } \\
\text { in Tropical Africa }\end{array}$ & \\
\hline $1921-1924$ & & $\begin{array}{l}\text { Phelps Stokes } \\
\text { Commissions on } \\
\text { Education in Africa }\end{array}$ & \\
\hline 1923 & $\begin{array}{l}\text { Imperial Education } \\
\text { Conference } \\
\text { Establishment of } \\
\text { ACNETA }\end{array}$ & & \\
\hline 1925 & $\begin{array}{l}\text { CO Memo on } \\
\text { Educational Policy in } \\
\text { British Tropical Africa } \\
\text { IMC Conference } \\
\text { on the Education of } \\
\text { Women and Girls in } \\
\text { Africa (London) }\end{array}$ & $\begin{array}{l}\text { Establishment of Jeanes } \\
\text { Schools in East and } \\
\text { Central Africa }\end{array}$ & \\
\hline 1926 & $\begin{array}{l}\text { Establishment of the } \\
\text { IIALC } \\
\text { Le Zoute (IMC) } \\
\text { Conference on } \\
\text { Colonial Education }\end{array}$ & & \\
\hline 1927 & $\begin{array}{l}\text { ACNETA report on } \\
\text { Vernacular Languages } \\
\text { in African education }\end{array}$ & & \\
\hline 1929 & $\begin{array}{l}\text { Colonial Development } \\
\text { Act (establishment of } \\
\text { ACEC) }\end{array}$ & & \\
\hline
\end{tabular}


Table 2.1 (continued)

\begin{tabular}{|c|c|c|c|}
\hline Date & Britain & British Africa & South Africa Union \\
\hline 1929-1930 & $\begin{array}{l}\text { Memo on A Biological } \\
\text { Approach to Education } \\
\text { in East Africa (J. } \\
\text { Huxley) } \\
\text { Memo on Grants-in } \\
\text { Aid to Educational } \\
\text { Institutions }\end{array}$ & & \\
\hline 1931 & $\begin{array}{l}\text { International } \\
\text { Conference on the } \\
\text { African Child (LoN/ } \\
\text { Geneva) } \\
\text { British Commonwealth } \\
\text { Conference on } \\
\text { Education }\end{array}$ & & \\
\hline 1932-1934 & & & $\begin{array}{l}\text { Carnegie Commission } \\
\text { on Poor Whites in SA }\end{array}$ \\
\hline 1932 & & & $\begin{array}{l}\text { Native Economic } \\
\text { Commission }\end{array}$ \\
\hline 1934 & & & $\begin{array}{l}\text { New Era Fellowship } \\
\text { Conference (NEF) in } \\
\text { South Africa }\end{array}$ \\
\hline 1935 & & $\begin{array}{l}\text { CO Memo on } \\
\text { Education in African } \\
\text { Communities (no. 103) } \\
\text { Inter-Territorial Jeanes } \\
\text { Schools Conference } \\
\text { (Salisbury) }\end{array}$ & \\
\hline 1935-1936 & & 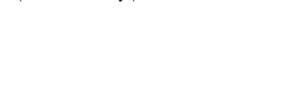 & $\begin{array}{l}\text { Inter-Departmental } \\
\text { Commission on Native } \\
\text { Education }\end{array}$ \\
\hline 1936-1938 & & $\begin{array}{l}\text { League of Nations } \\
\text { Nutrition Reports } \\
\text { CO Report on } \\
\text { Nutrition in the } \\
\text { Colonies }\end{array}$ & \\
\hline 1937 & & $\begin{array}{l}\text { CO Report on Higher } \\
\text { Education in East } \\
\text { Africa }\end{array}$ & \\
\hline 1939 & & $\begin{array}{l}\text { Establishment of Social } \\
\text { Services Department at } \\
\text { the CO }\end{array}$ & \\
\hline
\end{tabular}


Table 2.1 (continued)

\begin{tabular}{|c|c|c|c|}
\hline Date & Britain & British Africa & South Africa Union \\
\hline 1939-1945 & & World War II & \\
\hline \multirow[t]{2}{*}{1940} & UK Colonial & CO Report on the & \\
\hline & $\begin{array}{l}\text { Development and } \\
\text { Welfare Act }\end{array}$ & $\begin{array}{l}\text { Education of Women } \\
\text { and Girls in Africa }\end{array}$ & \\
\hline 1941 & & & $\begin{array}{l}\text { School Feeding } \\
\text { schemes in South } \\
\text { Africa }\end{array}$ \\
\hline 1942 & $\begin{array}{l}\text { UK Beveridge Report } \\
\text { on recommendations } \\
\text { for Welfare State }\end{array}$ & $\begin{array}{l}\text { CO Report on Juvenile } \\
\text { Delinquents in the } \\
\text { Colonies }\end{array}$ & \\
\hline \multirow[t]{5}{*}{1943} & & CO Nutrition & Reports on Adult \\
\hline & & Committee of the & Education/Vocational \\
\hline & & British Empire & and Technical \\
\hline & & Establishment of $\mathrm{CO}$ & Education/Welfare and \\
\hline & & $\begin{array}{l}\text { Advisory Committee } \\
\text { on Social Welfare }\end{array}$ & Health commissions \\
\hline \multirow[t]{2}{*}{1944} & Butler Act-Free & CO Report on Mass & \\
\hline & $\begin{array}{l}\text { Secondary Education in } \\
\text { the UK }\end{array}$ & $\begin{array}{l}\text { Education in African } \\
\text { Society }\end{array}$ & \\
\hline \multirow[t]{3}{*}{1945} & & CO Report on Higher & \\
\hline & & Education in the & \\
\hline & & Colonies & \\
\hline \multirow[t]{3}{*}{1948} & & CO Report on & \\
\hline & & Education for & \\
\hline & & Citizenship in Africa & \\
\hline
\end{tabular}

that characterized the post-colonial era. Looking back from what he saw as an "Age of Scepticism" in the late 1970s, Weiler sought to understand how the dreams of increasing equity had failed to be realized and why education had failed to contribute to the goals of equity in ways that had been taken for granted during the heyday of the "Development Decades."71 This chapter hopes to provide preliminary answers to these challenging questions (Table 2.1).

\footnotetext{
${ }^{71}$ Hans N. Weiler. "Education and Development: From the Age of Innocence to the Age of Scepticism," Comparative Education 14, no. 3 (1978): 179-198.
} 


\section{BIBLIOGRAPHY}

\section{Archival Sources}

British Parliamentary Papers and Colonial Office documents and archival references, as well as references from the IMC/CBMS collection at SOAS library, are cited in the footnotes.

The same applies to South African government papers.

\section{References}

Badroodien, Azeem. "A History of the Ottery School of Industries in Cape Town: Race, Welfare and Social Order in the Period 1937 to 1968." PhD diss., University of the Western Cape, 2000.

Blacklock, Mary. "The Welfare of Women and Children in the Colonies." Annals of Tropical Medicine and Parasitology 2 (1936): 221-265.

Campbell, Chloe. Race and Empire: Eugenics in Colonial Kenya. Manchester: Manchester University Press, 2006.

Carnoy, Martin. Education and Cultural Imperialism. New York: David McKay, 1974.

Cell, John. Hailey: A Study of British Imperialism, 1872-1969. Cambridge: Cambridge University Press, 1992.

Chisholm, Linda. "Reformatories and Industrial Schools in South Africa: A Study of Class, Colour and Gender in the Period Between 1882 and 1939." $\mathrm{PhD}$ diss., University of the Witwatersrand, 2000.

Constantine, Stephen. The Making of British Colonial Development Policy 19141940. London: Frank Cass, 1984.

Cooper, Frederick. Africa Since 1940: The Past of the Present. Cambridge: Cambridge University Press, 1996.

Cremin, Lawrence A. The Transformation of the School: Progressivism in American Education 1876-1957. New York: Vintage, 1964.

Darwin, John. "Decolonization and the End of Empire." In Oxford History of the British Empire, edited by Robin W. Winks, vol. V, 541-557. Oxford: Oxford University Press, 1999.

Duncan, David. "The Origins of the 'Welfare State' in Pre-apartheid South Africa." Institute of Commonwealth Studies Collected Seminar Papers on the Societies of Southern Africa, 1992, 106-119.

Green, Andy. Education and State Formation: The Rise of Education Systems in England, France and the USA. London: Macmillan, 1990.

Gregory, Robert G. Sydney Webb and East Africa. Berkeley: University of California, 1962.

Hailey, Lord. The African Survey. Oxford: Oxford University Press, 1938. 
Hargreaves, John D. Decolonization in Africa. London: Longman, 1988.

Hastings, Charlotte. "Gendered Education Between Metropole and Colony: Sara Burstall, Margaret Faith Wordsworth and Girl's Schooling in Inter-War Southern Nigeria.” PhD diss., University of Edinburgh, 2011.

Hellman, Ellen, ed. Handbook on Race Relations in South Africa. Johannesburg: SAIRR, 1949.

Hetherington, Penelope. British Paternalism and Africa. London: Frank Cass, 1978.

Hodge, Joseph M. Triumph of the Expert. Agrarian Doctrines of Development and the Legacies of British Colonialism. Athens, OH: University of Ohio Press, 2007.

Huxley, Julian. A Biological Approach to Native Education in East Africa, CO Africa (East) No. 1134 (1930); Biology and Its Place in Native Education in East Africa. London: HMSO, 1930.

Jensz, Felicity. "The 1910 Edinburgh World Missionary Conference and Comparative Colonial Education." History of Education 47, no. 3 (May 2018): 399-414. Special section: edited by Rebecca Swartz and Peter Kallaway on "Imperial, Global and Local Histories of Colonial Educational."

Jones, Thomas Jesse. Education in Africa. New York: Phelps Stokes Fund, 1922.

—. Education in East Africa. New York: Phelps Stokes Fund, 1924.

Kallaway, Peter. "Conference Litmus: The Development of a Conference and Policy Culture in the Inter-War Period with Special Reference to the New Education Fellowship and British Colonial Education in Southern Africa." In Transformations in Schooling: Historical and Comparative Perspectives, edited by Kim Tolley, 123-149. New York: Palgrave Macmillan, 2006.

. "Diedrich Westermann and the Ambiguities of Colonial Science in the Inter-War Era." Journal of Imperial and Commonwealth History 45, no. 6 (2017): 871-893.

. "Education, Health and Social Welfare in the late Colonial Context: The International Missionary Council and Educational Transition in the Inter-War Years with Specific Reference to Colonial Africa." History of Education 38, no. 2 (2009): 217-246.

- "Policy Challenges for Education in the 'New' South Africa: The Case for School Feeding in the Context of Social and Economic Construction." Transformation 31 (1996): 1-24.

-. "Science and Policy: Anthropology and Education in the British Colonial Africa During the Inter-War Years." Pedagogica Historica 48, no. 3 (2012): 411-430.

. "Volkskirche, Völkerkunde and Apartheid: Lutheran Missions, German Anthropology and Science in African Education." In Contested Relations: Protestantism Between Southern Africa and Germany from the 1930s to the Apartheid Era, edited by Hanns Lessing, Tilman Dedering, Jürgen Kampmann, and Dirkie Smit, 55-176. Wiesbaden: Harrassowitz Verlag, 2015. 
Kallaway, Peter, and Rebecca Swartz, eds. Empire and Education in Africa. New York: Peter Lang, 2017.

King, Kenneth. Pan Africanism and Education. Oxford: Clarendon Press, 1971.

Labaree, David. Education: Markets and the Public Good. New York: Routledge, 2007.

League of Nations. Final Report of the Mixed Committee of the League of Nations on the Relations of Nutrition to Health, Agriculture and Economic Policy. Geneva: LoN, 1937.

- The Problem of Nutrition. Geneva: LoN, 1936.

Lewis, Joanna. Empire and State-Building: War and Welfare in Kenya, 1925-52. Oxford: James Currey, 2000.

Lugard, Lord. Dual Mandate in Tropical Africa. London: Frank Cass, 1922.

Malinowski, Bronislaw. "Native Education and Culture Contact." International Review of Missions 25 (1936): 480-515.

- "The Rationalization of Anthropology and Administration." Africa 3, no. 4 (1930): 405-430.

Marks, Shula. "Industrialization, Rural Health, and the 1944 National Health Services Commission in South Africa." In The Social Basis of Health and Healing in Africa, edited by Steven Frierman and John M. Janzen, 132-161. Berkeley: UCLA Press, 1992.

Marshall, Dominique. "Children's Rights in Imperial Political Cultures: Missionary and Humanitarian Contributions to the Conference on the African Child of 1931." International Journal of Children's Rights 12 (2004): 273-318.

Nwauwa, Appolos O. "The British Establishment of Universities in Tropical Africa, 1920-48: A Reaction Against the Spread of American 'Radical' Influences." Cabiers d'Etudes africaines 130 (1993): 1247-1274.

Oldham, J. H. White and Black in Africa: A Critical Examination of the Rhodes Lectures of General Smuts. London: Longmans, 1930.

Paton, Alan. Diepkloof: Reflections on Diepkloof Reformatory. Cape Town: David Philip, 1987.

Ravitch, Diane. Left Back: A Century of Failed School Reforms. New York: Simons \& Schuster, 2001.

Rawson, W., ed. Education in a Changing Commonwealth. London: HMSO, 1931.

Richards, Audrey. Hunger and Work in a Savage Tribe: A Functional Study of Nutrition Among the Southern Bantu. London: George Routledge, 1932.

- Land, Labour and Diet in Northern Rhodesia: An Economic Study of the Bemba Tribe. London: OUP/IAI, 1939.

Sanderson, Michael. Education, Economic Change and Society in England, 17801870. London: Macmillan, 1983.

Sarraut, Albert. La Mise en valeur des Colonies françaises. Paris: Payot, 1923. 
Schlunk, Martin. Die Schulen für Eingeborene in den deutschen Schutzgebieten. Hamburg: Hamburgischen Kolonialinstituts/L. Freidrichsen \& Co., 1914.

Scott, John. "Education and Nutrition in the Colonies." Oversea Education IX, no. 1 (October 1937): 39-40.

Sharp, Evelyn. The African Child: An Account of the International Conference on African Children. Geneva: S.I. Longman, 1931.

Silver, Harold. Equal Opportunity in Education. London: Methuen, 1973.

Tilley, Helen. Africa as a Living Laboratory. Chicago: University of Chicago Press, 2011.

Tyack, David, and Larry Cuban. Tinkering Towards Utopia: A Century of Public School Reform. Cambridge, MA: Harvard University Press, 1995.

Watson, Keith, ed. Education in the Third World. London: Croom Helm, 1982.

Weiler, Hans N. "Education and Development: From the Age of Innocence to the Age of Scepticism." Comparative Education 14, no. 3 (1978): 179-198.

Whitehead, Clive. "The Education of Women and Girls: An Aspect of British Colonial Policy." Journal of Educational Administration and History 16, no. 2 (1984): 24-34.

Welch, Janet. "The Goal of Women's Education in Africa." Oversea Education XI, no. 2 (1940): 65-72.

Whyte, Quentin. Native School Feeding. Johannesburg: SAIRR, 1949.

Wrong, Margaret. "The Education of African Women in a Changing World." In rearbook of Education, 497-520. London: Evans Bros., 1940.

Open Access This chapter is licensed under the terms of the Creative Commons Attribution 4.0 International License (http://creativecommons.org/licenses/ by $/ 4.0 /)$, which permits use, sharing, adaptation, distribution and reproduction in any medium or format, as long as you give appropriate credit to the original author(s) and the source, provide a link to the Creative Commons license and indicate if changes were made.

The images or other third party material in this chapter are included in the chapter's Creative Commons license, unless indicated otherwise in a credit line to the material. If material is not included in the chapter's Creative Commons license and your intended use is not permitted by statutory regulation or exceeds the permitted use, you will need to obtain permission directly from the copyright holder.

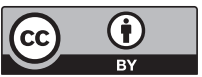

